\title{
A Survey for Federally Listed Grassland Birds at First Nations Reserves
}

\author{
Scott D. Stevens and Troy I. Wellicome ${ }^{1}$
}

Canadian Wildlife Service, Environmental Conservation Branch, Prairie and Northern Region, Room 200, 4999-98 ${ }^{\text {th }}$ Avenue, Edmonton, Alberta T6B 2X3 Canada; e-mail: troy.wellicome@ ec.gc.ca

${ }^{1}$ Corresponding Author

Stevens, Scott D., and Troy I. Wellicome. 2005. A survey for federally listed grassland birds at First Nations Reserves, Canadian Field-Naturalist 119(4): 490-496.

We surveyed native and non-native grassland for federally listed grassland bird species at Reserves and/or Treaty Land Entitlements (TLE) belonging to five First Nations in the prairie ecozone of Canada. Ferruginous Hawk (Buteo regalis - of special concern), Loggerhead Shrike (Lanius ludovicianus - threatened), and Long-billed Curlew (Numenius americanus - of special concern) were observed at five of 335, three of 361, and five of 329 survey points within their respective geographic ranges. Sprague's Pipit (Anthus spragueii-threatened) was observed at 69 of 361 survey points and accounted for $84 \%$ of sites with listed birds. Estimates of proportions of native and non-native grassland within $400 \mathrm{~m}$ of survey points indicated that Sprague's Pipit preferred native grassland. Despite special effort, the Burrowing Owl (Athene culicularia-endangered) was not observed, although a nest from a previous year was encountered. We recorded the greatest number of species and individuals on reserves located in mixed and moist-mixed grasslands that contained large portions of native grassland. In many instances, field assessments revealed unsuitable habitat at sites that remote-sensing data classified as suitable.

Key Words: Burrowing Owl, Athene cunicularia, Ferruginous Hawk, Buteo regalis, Loggerhead Shrike, Lanius ludovicianus, Long-billed Curlew, Numenius americanus, Sprague's Pipit, Anthus spragueii, grassland species at risk, habitat assessment, remote sensing, Canada.

The Canadian prairies are home to more federally listed birds than any other region of Canada (COSEWIC $\left.2003^{*}\right)$. With the coming into force of The Species at Risk Act (SARA) in 2004, the demand for knowledge of locations of species at risk increased in Canada, particularly on federal lands. Inventories for listed bird species have been conducted in National Parks (e.g., Wynn and Jensen 1998*), National Wildlife Areas (e.g., Haber 1995*), and on Department of National Defence lands (e.g., Banasch and Barry 1998*; Dale et al. in press). More recently, surveys have been undertaken on Agriculture and Agri-foods Canada lands (e.g., G. L. Holroyd, personal communication). However, we are aware of no surveys for listed species on First Nations Reserves, even though Reserves are included as federal lands in the context of SARA.

Our objective was to survey Reserves and Treaty Land Entitlements (TLE) for grassland bird species listed as endangered (Burrowing Owl, Athene cunicularia), threatened (Loggerhead Shrike, Lanius ludovicianus; Sprague's Pipit, Anthus spragueii) or of special concern (Ferruginous Hawk, Buteo regalis; Long-billed Curlew, Numenius americanus). Ideally, such surveys should be conducted during the months of May and June, when these birds are breeding and most conspicuous (see Discussion). However, because of delays in securing permission for surveys, four of our surveys occurred between late-June until mid-July and one could not be conducted until mid-August. Nevertheless, through point counts and habitat description, we were able to gain a first indication of the relative importance of these Reserves to listed grassland birds. We were granted permission by five First Nations to conduct surveys on their lands within the prairie ecozone (Figure 1). In Alberta, we surveyed the Blood (\#148) and Siksika (\#146) Reserves. In Saskatchewan, we surveyed Nekaneet Cree TLE, Piapot Cree First Nation Reserve (\#75) and TLE, and Assiniboine (Carry the Kettle Nakota Band) Reserve (\#76). Here we present counts of listed birds observed at each of these Reserves or TLE. We also summarize visual estimates of habitat proportions at point-count locations, and summarize habitat at the landscape level with remote sensing data. Lastly, we use habitat data, current species ranges, knowledge of species biology, and timing of the surveys to interpret presence/absence of listed species and to infer the relative importance of these lands to conservation of grassland bird species at risk.

\section{Methods}

\section{Habitat Assessment with Remote Sensing}

Classified land-cover information was obtained for Alberta and Saskatchewan from the Prairie Farm Rehabilitation Administration's (PFRA) land cover (Ashton $2001 *)$. We examined the following land-cover categories: grassland (includes both native and non-native grassland), cultivated, treed, shrub-covered, and wetland. We used ArcView 3.2 ${ }^{\circledR}$ to summarize land-cover types within the boundaries of each reserve.

\section{Surveys}

Each survey was conducted some time between 25 June and 14 August 2003 (Table 1) by at least two of five observers. All observers were trained, by Canadian 


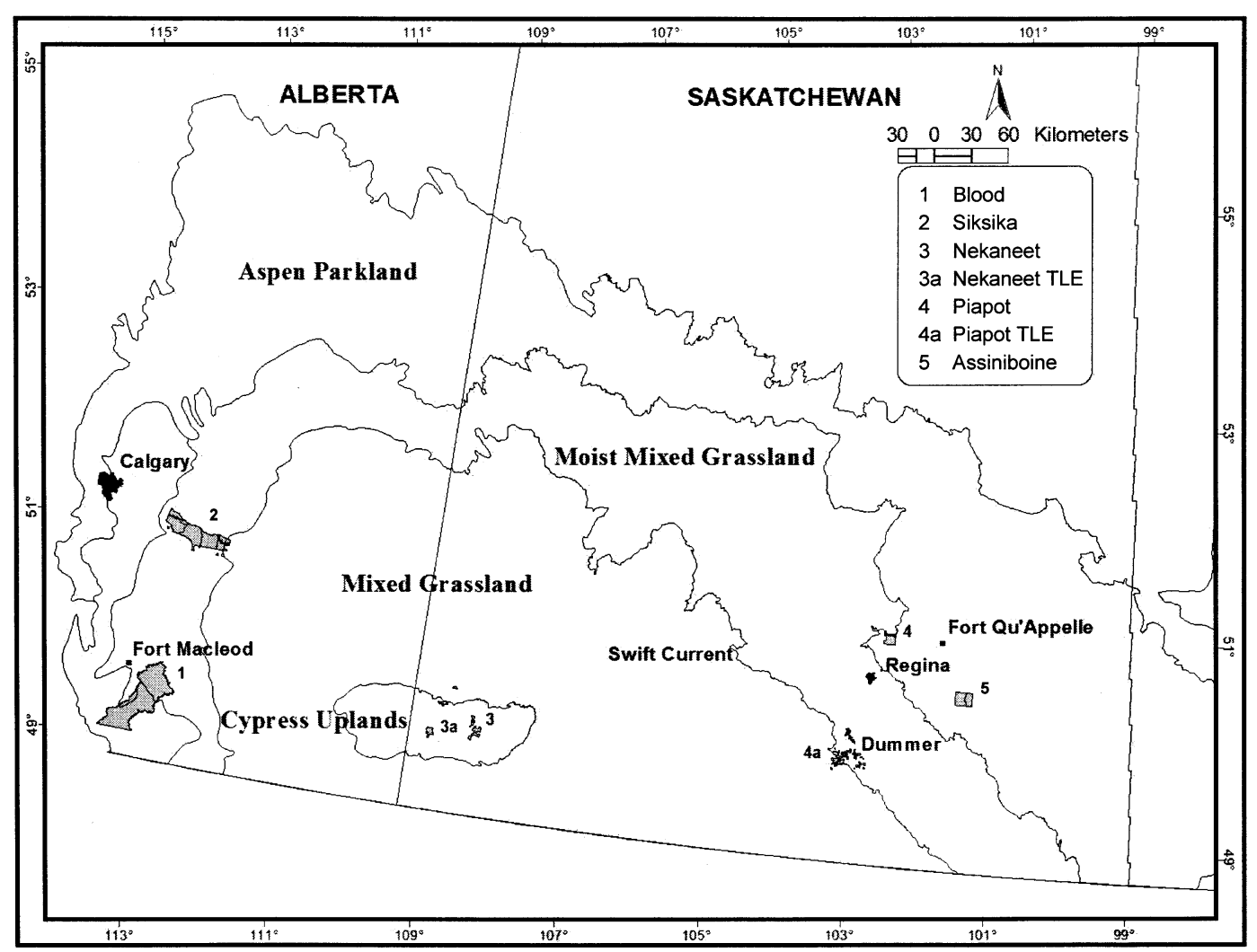

FIGURE 1. First Nations Reserves and Treaty Land Entitlements (TLE) that were surveyed for federally listed grassland birds in this study. First Nations lands are shown in relation to provincial borders, ecoregional boundaries, and nearest cities or towns.

Wildlife Service staff, in the visual and auditory identification of the target species and those non-target species that had the most potential to be confused with target species. All of the Reserves and TLE contain areas of cultivated land and treed habitat. These habitat types were not surveyed because they are generally unsuitable for the target species (Table 2). Areas were selected for point-count surveys only if surrounding land-cover was predominantly grassland (native or non-native). All suitable tracts of grassland were then covered by survey point locations that were separated at $800 \mathrm{~m}$ intervals in each cardinal direction to form a uniform grid. We accessed point-count stations by truck or ATV (All-Terrain Vehicle). At each point, UTM coordinates were recorded from a hand-held Garmin ${ }^{\circledR}$ GPS 12 XL. An individual observer conducted a three-minute passive scan, using binoculars to identify and record all target species. Due to the relative rarity of the Burrowing Owl, we also used a portable CD player (Citizen ${ }^{\circledR}$ JCD4109) to broadcast recorded breeding calls of a male Burrowing Owl while scanning for an additional three minutes. Sprague's Pipit were identified by their territorial songs during the passive phase of the scan and all other species by direct observation with binoculars. After completion of the six-minute scan, we estimated percent cover of several habitat types within a 400-m (50.2 ha) radius: native grassland, non-native grassland, cultivated land, trees, shrubs, and wetlands. This habitat assessment was performed to estimate habitat composition, at the same scale as the bird counts, using the same variables identified in the PFRA database. Habitat assessment in the field also enabled us to distinguish native from non-native grassland.

\section{Results}

Potential Listed Bird Species and Habitat Characteristics at Reserves

The Blood Reserve, surveyed 12-14 August, is at the western edge of the ranges of all five listed species: Burrowing Owl (Wellicome and Holroyd 2001), Loggerhead Shrike (Yosef 1996), Sprague's Pipit (Robbins and Dale 1999), Ferruginous Hawk (Bechard and Schmutz 1995), and Long-billed Curlew (Dugger and Dugger 2002). The Blood was the largest reserve in this study (Table 2), with $40 \%$ of overall land-cover classified as grassland and most of the remaining land classified as cultivated (Table 2). Remote sensing 
TABLE 1. Summary of listed grassland birds at First Nations Reserves and Treaty Land Entitlements (TLE) during 2003 pointcount surveys. BUOW = Burrowing Owl; FEHA = Ferruginous Hawk; LBCU = Long-billed Curlew; LOSH = Loggerhead Shrike; SPPI = Sprague's Pipit. Numbers for each species denote survey points at which they were detected. In parentheses is the total number of individuals detected.

\begin{tabular}{|c|c|c|c|c|c|c|c|c|c|}
\hline Reserve & $\begin{array}{c}\text { Ecoregion } \\
\text { listed species }\end{array}$ & $\begin{array}{c}\text { Potential \# } \\
\text { Survey }\end{array}$ & $\begin{array}{l}\text { Date of } \\
\text { Points }\end{array}$ & \# Survey & BUOW & FEHA & LBCU & $\mathrm{LOSH}$ & I SPPI \\
\hline Blood & Moist-mixed Grassland & 5 & 12-14 August & 96 & 0 & 1 & 1 & 0 & 1 \\
\hline Siksika & Moist-mixed Grassland & 5 & 25-27 June & 148 & $0 *$ & 2 & $4(6)$ & 3 & $44(52)$ \\
\hline Nekaneet TLE & Mixed Grassland & 5 & 9-11 July & 85 & 0 & 2 & 0 & 0 & $21(27)$ \\
\hline Piapot TLE & Moist-mixed Grassland & 4 & 7-8 July & 6 & 0 & 0 & - & 0 & 2 \\
\hline Piapot & Aspen Parkland & 2 & 7-8 July & 15 & - & - & - & 0 & 1 \\
\hline Assiniboine & Aspen Parkland & 2 & 3-4 July & 11 & 一 & - & - & 0 & 0 \\
\hline Total & & & & 361 & 0 & 5 & $5(7)$ & 3 & $69(83)$ \\
\hline
\end{tabular}

*One inactive Burrowing Owl nest site, which appeared to have been occupied in previous years, was noted at the Siksika reserve.

TABLE 2. Total hectares and \%cover of habitat types at First Nations Reserves and Treaty Land Entitlements (TLE) based on remote sensing. In parentheses, total number of hectares surveyed at each reserve and summary of habitat percentages within a 400-m radius of survey-points. Percentages of habitat types at survey-points reported as mean \pm standard error. For "Grassland", \%Native and \%Non-native was distinguished visually in the field.

\begin{tabular}{|c|c|c|c|c|c|c|c|}
\hline \multirow[t]{2}{*}{ Reserve } & \multirow[t]{2}{*}{ Total in ha } & \multicolumn{2}{|c|}{$\%$ Grassland } & \multirow[t]{2}{*}{$\%$ Cultivated } & \multirow[t]{2}{*}{$\%$ Trees } & \multirow[t]{2}{*}{$\%$ Shrubs \% } & \multirow[t]{2}{*}{$\%$ Wetlands } \\
\hline & & (\% Native) & (\%Non-native) & & & & \\
\hline \multirow[t]{2}{*}{ Blood } & 140124 & 40.3 & 58.9 & 0.2 & 0.1 & $<0.1$ & \\
\hline & (4823) & $(77.8 \pm 2.6)$ & $(0.8 \pm 0.4)$ & $(19.3 \pm 2.5)$ & $(0.3 \pm 0.2)$ & $(0.4 \pm 0.1)$ & $(1.5 \pm 0.3)$ \\
\hline \multirow[t]{2}{*}{ Siksika } & 71339 & 68.1 & 27.1 & 0.9 & 1.5 & 0.0 & \\
\hline & $(7436)$ & $(88.8 \pm 1.6)$ & $(2.3 \pm 0.9)$ & $(5.7 \pm 1.3)$ & $(0.9 \pm 0.4)$ & $(0.7 \pm 0.2)$ & $(1.8 \pm 0.2)$ \\
\hline \multirow[t]{2}{*}{ Nekaneet TLE } & 10725 & 95.2 & 2.0 & 0.1 & 1.7 & 0.0 & \\
\hline & $(4271)$ & $(69.1 \pm 3.2)$ & $(15.3 \pm 2.8)$ & $(5.2 \pm 1.4)$ & $(3.1 \pm 0.9)$ & $(6.3 \pm 0.7)$ & $(1.1 \pm 0.2)$ \\
\hline \multirow[t]{2}{*}{ Piapot TLE } & 11244 & 2.6 & 91.0 & 0.3 & 1.9 & 3.2 & \\
\hline & (301) & $(23.6 \pm 5.5)$ & $(34.1 \pm 8.8)$ & $(35.9 \pm 10.0)$ & $(5.3 \pm 4.9)$ & $(0.5 \pm 0.2)$ & $(0.7 \pm 0.3)$ \\
\hline \multirow[t]{2}{*}{ Piapot } & 8140 & 38.4 & 44.4 & 7.4 & 2.2 & 5.2 & \\
\hline & (754) & $(0.3 \pm 0.3)$ & $(67.7 \pm 10.4)$ & $(8.3 \pm 8.3)$ & $(23.0 \pm 10.6)$ & $(0.5 \pm 0.2)$ & $(0.2 \pm 0.2)$ \\
\hline \multirow[t]{2}{*}{ Assiniboine } & 16375 & 76.3 & 19.4 & 3.9 & 0.0 & 0.3 & \\
\hline & $(553)$ & $(14.0 \pm 6.2)$ & $(65.0 \pm 10.8)$ & $(0 \pm 0)$ & $(15.7 \pm 5.0)$ & $(2.8 \pm 1.5)$ & $(2.7 \pm 1.4)$ \\
\hline \multirow[t]{2}{*}{ Overall } & 259197 & $54.6 \pm 11.5$ & $40.5 \pm 12.9$ & $5.4 \pm 3.4$ & $1.4 \pm 0.4$ & $1.6 \pm 0.8$ & \\
\hline & $(18138)$ & $(74.7 \pm 1.6)$ & $(9.1 \pm 1.2)$ & $(10.4 \pm 1.1)$ & $(2.2 \pm 0.5)$ & $(2.0 \pm 0.3)$ & $(1.5 \pm 0.1)$ \\
\hline
\end{tabular}

attributed very little land cover to trees and shrubs. Overall land-cover estimates for trees and shrubs were similar to what we observed at survey-points (Table 2). Visual estimates at point-count locations revealed that most grassland is native.

The Siksika Reserve is also near the western edge of the ranges of all target species. We surveyed the Siksika Reserve 25-27 June (Table 1). It was the second largest of the five reserves (Table 2), with $68 \%$ of overall land-cover classified as grassland and scarce tree and shrub cover (Table 2). Visual estimates at point-count locations revealed that grasslands were almost exclusively native. Tree and shrub cover at survey-points was similar to overall land-cover estimates (Table 2).

Located northeast of Cypress Hills, the Nekaneet Cree Nation Reserve contains rolling habitat that is extensively treed and thus unsuitable for grassland species. However, Nekaneet TLE, which is separate from the reserve proper (Figure 1), is within the ranges of all of the target species and has suitable habitat. On Nekaneet TLE, remote sensing classified $95 \%$ of land-cover as grassland, with very minor shrub and cultivation coverage (Table 2). However, visual estimates from survey points revealed that as much as $15 \%$ of the grassland is non-native and that trees and shrubs are in somewhat higher proportions within the grasslands than is indicated by remote sensing.

Piapot Reserve is within the range of the Loggerhead Shrike and Sprague's Pipit and is near the eastern edge of the Burrowing Owl and Ferruginous Hawk ranges, at the transition from Moist Mixed Grassland to Aspen Parkland. The Reserve was surveyed 7-8 July (Table 1). Although remote sensing classified $38 \%$ of the Reserve as grassland, visual estimates indicated that very little native grassland remains on the Reserve, most having been converted to nonnative pasture. These pastures contained a much higher 
TABLE 3. Summary of habitat characteristics for points at which listed species were observed. Percentages reported as mean \pm standard error. The category 'Present' includes locations where any of the five listed species was observed. "Absent" includes all locations at which listed species were not observed.

\begin{tabular}{|c|c|c|c|c|c|c|c|}
\hline Species & $N$ & $\%$ Native & $\%$ Tame & $\%$ Cultivated & $\%$ Tree & \%Shrub & $\%$ Wetlands \\
\hline FEHA & 5 & $90.6 \pm 3.2$ & $0 \pm 0$ & $2.0 \pm 2.0$ & $0.4 \pm 0.4$ & $2.2 \pm 2.0$ & $4.8 \pm 3.9$ \\
\hline LBCU & 5 & $77.4 \pm 13.3$ & $0 \pm 0$ & $21.6 \pm 13.4$ & $0 \pm 0$ & $0 \pm 0$ & $1.0 \pm 0.3$ \\
\hline LOSH & 3 & $97.3 \pm 0.9$ & $0 \pm 0$ & $0 \pm 0$ & $1.0 \pm 0.6$ & $1.3 \pm 0.7$ & $0.3 \pm 0.3$ \\
\hline SPPI & 69 & $87.7 \pm 2.3$ & $1.8 \pm 1.0$ & $3.5 \pm 1.5$ & $1.8 \pm 1.1$ & $4.0 \pm 1.4$ & $1.2 \pm 0.2$ \\
\hline Present & 82 & $86.2 \pm 2.4$ & $1.6 \pm 0.9$ & $4.6 \pm 1.6$ & $1.7 \pm 0.9$ & $3.7 \pm 1.0$ & $1.4 \pm 0.3$ \\
\hline Absent & 279 & $71.6 \pm 1.9$ & $11.2 \pm 1.5$ & $12.0 \pm 1.3$ & $2.4 \pm 0.6$ & $1.5 \pm 0.3$ & $1.5 \pm 0.2$ \\
\hline
\end{tabular}

FEHA - Ferruginous Hawk; LBCU - Long-tailed Curlew; LOSH - Loggerhead Shrike; SPPI - Sprague's Pipit.

proportion of trees than is indicated by remote sensing (Table 1).

Piapot TLE, south and west of the Piapot Reserve (Figure 1), is well within Moist Mixed Grassland but east of the range of the Long-billed Curlew. Ninety-one percent of the land is cultivated, and visual estimates indicated that remaining grassland (3\%) contains more non-native than native grassland. Trees and shrubs were in higher proportion within the areas surveyed than is indicated by remote sensing (Table 2).

Assiniboine Reserve is located in the Aspen Parkland, outside of the current ranges of the Burrowing Owl, Ferruginous Hawk, and Long-billed Curlew, but inside the range of both the Loggerhead Shrike and Sprague's Pipit. Remote sensing classified $76 \%$ of land cover in the Assiniboine Reserve as grassland (Table 2). Visual estimates at survey-points, however, revealed that $65 \%$ of grassland was non-native and that trees and shrubs were in higher proportions than indicated by remote sensing.

\section{Species Observations}

Listed birds were observed at 82 of the 361 (23\%) survey points (Table 1). Of the 82 points with listed birds, Sprague's Pipit was observed at $69(84 \%)$; it was relatively common at Siksika (44 of 148 points; $30 \%$ ), Nekaneet TLE (21 of 85 points; $25 \%$ ), and Piapot TLE (two of 6 points; 33\%), but was seldom detected at the Blood (1 of 96 points; $1 \%$ ) and Piapot (one of 15 points; 7\%) Reserves. Ferruginous Hawks were observed at one location on the Blood Reserve and two locations on the Siksika Reserve and Nekaneet TLE, but were not detected at Piapot TLE, though this land is within their geographic range. Long-billed Curlews were most abundant at Siksika Reserve (four of 148 points; six individuals; Table 1) but were encountered only at one other location, on the Blood Reserve. Loggerhead Shrikes were observed only at Siksika (three of 148 points; $2 \%$ ).

Despite special effort to locate them (i.e., taped calls), the Burrowing Owl was the only listed species not observed on any of the Reserves. However, we did find two burrows (10 m apart) at Siksika that we judged, based on several small rodent skeletal remains on and near the mounds, had previously been a Burrowing Owl nest and roost. There were no owl pellets or whitewash, and burrow entrances were beginning to collapse, indicating the site had not been used for at least one year (see California Burrowing Owl Consortium 1997).

To infer habitat selection for Sprague's Pipits, we compared visual estimates of percentage of native grassland at point locations where pipits were present versus where they were absent. We considered only Nekaneet TLE and Siksika, where the species was observed in highest abundance and where timing of surveys was concurrent with territorial songs (Robbins 1998). At both Nekaneet TLE and Siksika, the percentage of native prairie was higher at locations where Sprague's Pipits were present (Table 3). Although sample sizes were small, Ferruginous Hawks, Long-billed Curlews, and Loggerhead Shrikes showed a similar pattern (Table 3 ).

\section{Discussion}

The timing of these surveys most likely reduced detection rates of some target species, particularly the August survey at the Blood Reserve. Although Burrowing Owls typically begin leaving Canada on southward migration during September and October (Todd et al. 2003), males are most aggressive and conspicuous during egg laying and brood rearing (May through June) and thus more likely to respond to call playbacks during that time (Haug and Didiuk 1993; Shyry et al. 2001). Long-billed Curlews depart from northern parts of their breeding range by mid-July and from all parts of their breeding range by mid-August (Dugger and Dugger 2002). Sprague's Pipits perform persistent displays and songs from mid-April through the third week of May, with another period of elevated display from mid-June to mid-July; however, their singing ceases almost entirely by mid-August (Robbins 1998). Ferruginous Hawks (Bechard and Schmutz 1995) and Loggerhead Shrikes (Yosef 1996) do not begin migration until September, and these species may be most easily detected during breeding in May and June. Though timing for the surveys in this study was suboptimal, the relative magnitude of our counts of listed 
grassland birds corresponded roughly to overall estimates of abundance for each species in Canada.

The Burrowing Owl is listed as endangered in Canada (Wellicome and Haug 1995*; COSEWIC 2003*) and has been essentially extirpated from Manitoba. The range of this species within southern Alberta and Saskatchewan is currently half the size it was 20-30 years ago (Wellicome and Holroyd 2001). Fewer than 800 pairs are estimated to remain on the Canadian Prairies (Todd 2005*), and our survey provides support for the rarity of this species. Like many areas across the Canadian prairies, the Blood and Siksika reserves, and Nekaneet TLE, appear to contain suitable but vacant Burrowing Owl habitat.

The Ferruginous Hawk, listed as a species of special concern in Canada (COSEWIC 2003*), still occupies many areas where it was reported in historical times, but has declined at the northern edge of its range in Alberta, Saskatchewan, and Manitoba (Schmutz 1995*; Schmutz et al. 1994*). The breeding population in Canada is estimated at 2000-4000 pairs (Schmutz 1995*; Schmutz et al. 1994*). Although Ferruginous Hawks prefer elevated nest sites, such as isolated trees or platforms, they occur in large tracts of open, generally arid habitats dominated by grasses or sagebrush (Bechard and Schmutz 1995). Schmutz (1989) showed that they were more abundant where levels of cultivation were low. Our results agree with these previous studies, as Ferruginous Hawks were found on reserves with the largest areas of native grassland.

Prairie populations of the Loggerhead Shrike, listed in Canada as threatened (Cadman 1985*; COSEWIC $\left.2003^{*}\right)$, have declined in numbers since the $1960 \mathrm{~s}$ (Yosef 1996), and the northern limit of their range has retracted (Telfer et al. 1989). The most recent population estimate is 2500 pairs in Alberta, 7000 pairs in Saskatchewan, and 500 pairs in Manitoba (Johns et al. 1994*). All of the Reserves we surveyed were within the geographic range of Loggerhead Shrikes, but we found shrikes only at Siksika. Siksika contains sporadic shrub and tree cover, which Loggerhead Shrikes require for nesting habitat (Yosef 1996), and large areas of grassland to support prey species of Loggerhead shrikes. Although their abundance is correlated with availability of pastureland (Gawlik and Bildstein 1993), Loggerhead Shrikes occur at relatively low densities (Telfer 1993) and thus may be more difficult to detect than Long-billed Curlews, Ferruginous Hawks, and vocalizing Sprague's Pipits.

Long-billed Curlews, listed as a species of special concern in Canada (De Smet 1992*), are now considered extirpated in Manitoba (De Smet 1992*; Hill $1998 *)$ and very rare in areas of southeastern Saskatchewan, where they were once common (Renaud 1980). Although the population in Alberta has been estimated at approximately 24000 (assuming equal sex ratio; Saunders 2001*), it is suspected they are declining rapidly in eastern parts of their range, including
Saskatchewan (De Smet 1992*; Saunders 2001*). Long-billed Curlews nest close to wetter areas in short grass or mixed-grassland habitat (Hooper and Pitt 1996*) and avoid areas with trees and high densities of shrubs (Pampush and Anthony 1993). We did not observe Long-billed Curlews at Nekaneet TLE, which is within their geographic range, perhaps because the grasslands there contain few wetlands and relatively high shrub-cover. Habitat characteristics were generally similar between Blood and Siksika Reserves, but we observed more Long-billed Curlews at Siksika. One difference that may help explain this result is the lower proportion of wetlands at the Blood Reserve. Perhaps more importantly, however, our survey at the Blood Reserve was late, so many Long-billed Curlews may have already started to migrate south.

Sprague's Pipit is listed as threatened in Canada (COSEWIC 2003*). Although still locally abundant, populations of Sprague's Pipit have been declining rapidly in parts of their range, with the greatest decline occurring in Canada's prairie provinces (Sauer et al. 1997*). Populations in Alberta and Saskatchewan, where highest densities occur, have declined by $9.4 \%$ and $5.4 \%$ per year, respectively (Prescott and Davis 1998*). Sprague's Pipits prefer native grassland, rarely being found in cultivated fields or where native grasses have been replaced by introduced species (Robbins and Dale 1999). Accordingly, the only Reserve where Sprague's Pipits were not observed in this study was the Assiniboine, which is composed predominantly of non-native grassland. The species was found in relative abundance at the Nekaneet TLE and the Siksika Reserve, which both contain substantial proportions of native grassland. The Blood Reserve, which also contains large tracts of native grassland, albeit at the western edge of the range, probably contains a larger population of Sprague's Pipit than our late survey would suggest. By mid-August male territorial vocalizations are rare (Robbins 1998) and thus Sprague's Pipit are exceedingly difficult to detect at that time.

Our comparison of percentage native grassland between those sites at Siksika and Nekaneet TLE where Sprague's Pipit were and were not detected (in surveys concurrent with male territorial songs) support other studies showing a preference for native grassland by this species (Robbins and Dale 1999). Although sample sizes were small, Ferruginous Hawks, Long-billed Curlews, and Loggerhead Shrikes were also observed at point locations with high percentages of native prairie, suggesting the importance of native grasslands to these species.

The PFRA land-cover data can be misleading for large-scale habitat assessments because they do not distinguish native from non-native grassland, and tend to underestimate shrub and tree cover within grasslands. Based on visual habitat estimates, the Assiniboine and Piapot Reserves, which are both in aspen parkland, contained high proportions of trees and tame pasture 
and were of relatively little importance to listed grassland birds. In contrast, the Siksika and Blood Reserves, which are in moist-mixed grassland, and Nekaneet TLE, which is in mixed grassland, each contain relatively large proportions of native grassland and appear to be important areas for listed grassland birds.

\section{Acknowledgments}

Funding support for this project was provided by the Canadian Wildlife Service, in the Prairie and Northern Region of Environment Canada. We extend our thanks to Dave Duncan, who encouraged us to undertake these surveys, and to the Blood, Siksika, Nekaneet Cree, Piapot Cree, and Carry the Kettle First Nations for granting us access to their lands. For excellent assistance in the field, we thank Stephanie Grossman, David Junor, and Joann Skilnick. We also thank Geoffrey L. Holroyd, of the Canadian Wildlife Service, for sharing a personal communication about his species-at-risk surveys on Agriculture and Agri-foods Canada lands. Special thanks to David Junor for using the PFRA GIS dataset to calculate proportions of land-cover within each reserve and also for preparing Figure 1.

Documents Cited [marked * in text]

Ashton, J. 2001. PFRA's Generalized Land Cover, Version 1. Prairie Farm Rehabilitation Administration, Agriculture and Agri-foods Canada, Regina, Saskatchewan. http://www. agr.gc.ca/pfra/gis/.

Banasch, U., and S. J. Barry. 1998. Raptor component report: Canadian Forces Base Suffield National Wildlife Area wildlife inventory. Unpublished Canadian Wildlife Service Report, Edmonton, Alberta. 51 pages.

Cadman, M. D. 1985. Status report on the Loggerhead Shrike in Canada. Committee on the Status of Endangered Wildlife in Canada, Ottawa, Ontario. 96 pages.

COSEWIC. 2003. Canadian Species at Risk, May 2003. Committee on the Status of Endangered Wildlife in Canada, Ottawa, Ontario. 43 pages.

De Smet, K. D. 1992. Status report on the Long-billed Curlew Numenius americanus in Canada. Committee on the Status of Endangered Wildlife in Canada, Ottawa, Ontario. 44 pages.

Haber, E. 1995. Species at Risk and invasive plants of National Wildlife Areas and Migratory Bird Sanctuaries. Unpublished Canadian Wildlife Service Report, Ottawa, Ontario. 170 pages.

Hill, D. P. 1998. Status of the Long-billed Curlew (Numenius americanus) in Alberta. Alberta Environmental Protection, Fisheries and Wildlife Management Division, and Alberta Conservation Association, Wildlife Status Report (16), Edmonton, Alberta. 20 pages.

Hooper, T. D., and M. D. Pitt. 1996. Breeding bird communities and habitat associations in the grasslands of the Chilcotin Region, British Columbia. Canada-British Columbia Partnership Agreement on Forest Resource Development: FRDA II.

Johns, B., E. Telfer, M. Cadman, D. Bird, R. Bjorge, K. De Smet, W. Harris, D. Hjertaas, P. Laporte, and R. Pittaway. 1994. National Recovery Plan for the Loggerhead Shrike. Recovery of Nationally Endangered Wildlife Report number 7, Ottawa, Ontario. 32 pages.
Prescott, D. R. C., and S. K. Davis. 1998. Status Report on the Sprague's Pipit Anthus spragueii in Canada. Status Report to the Committee on the Status of Endangered Wildlife in Canada, Ottawa, Ontario. 33 pages.

Sauer, J. R., J. E. Hines, G. Gough, I. Thomas, and B. G. Peterjohn. 1997. The North American breeding bird survey results and analysis, Version 96.4. Patuxent Wildlife Research Center, Laurel, Maryland. http://www.mbr-pwrc. usgs.gov/bbs/bbstext.html

Saunders, E. J. 2001. Population estimate and habitat associations of the Long-billed Curlew (Numenius americanus) in Alberta. Alberta Fish and Wildlife Division, Species at Risk Report number 25, Edmonton, Alberta. 57 pages.

Schmutz, J. K. 1995. Updated Status Report on the Ferruginous Hawk, Buteo regalis, in Canada. Committee on the Status of Endangered Wildlife in Canada, Ottawa, Ontario. 18 pages.

Schmutz, J. K., S. H. Brechtel, K. D. De Smet, D. G. Hjertaas, C. S. Houston, and G. L. Holroyd. 1994. National Recovery Plan for the Ferruginous Hawk. Report number 11. Recovery of Nationally Endangered Wildlife Committee, Ottawa, Ontario. 35 pages.

Todd, L. D. 2005. Status of the Burrowing Owl (Athene cunicularia) in Alberta: update 2005. Alberta Sustainable Resource Development, Wildlife Status Report Number 11 (Update 2005), Edmonton, Alberta. 28 pages.

Wellicome, T. I., and E. A. Haug. 1995. Second update of status report on the Burrowing Owl Speotyto cunicularia in Canada. Committee on the Status of Endangered Wildlife in Canada, Ottawa, Ontario. 23 pages.

Wynn, M., and O. Jensen. 1998. Sage grouse monitoring, 1997. Grasslands National Park Annual Report Volume 3: 54-56.

\section{Literature Cited}

Bechard, M. J., and J. K. Schmutz. 1995. Ferruginous Hawk (Buteo regalis). In The Birds of North America (172). Edited by A. Poole and F. Gill. The Academy of Natural Sciences, Philadelphia, Pennsylvania; The American Ornithologists' Union, Washington, D.C.

California Burrowing Owl Consortium. 1997. Burrowing owl survey protocol and mitigation guidelines. Raptor Research Reports 9: 171-177.

Dale, B. C., M. R. Norton, P. S. Taylor, and J. P. Goossen. In press. Protecting the regional avifauna-topographic, habitat, and bird diversity in a prairie reserve. Canadian Field-Naturalist.

Dugger, B. D., and K. M. Dugger. 2002. Long-billed Curlew (Numenius americanus). In The Birds of North America, (62B). Edited by A. Poole and F. Gill. The Academy of Natural Sciences, Philadelphia, Pennsylvania; The American Ornithologists Union, Washington, D.C.

Gawlik, D. E., and K. L. Bildstein. 1993. Seasonal habitat use and abundance of loggerhead shrikes in South Carolina. Journal of Wildlife Management 57: 352-357.

Haug, E. A., and A. B. Didiuk. 1993. Use of recorded calls to detect burrowing owls. Journal of Field Ornithology 64: 188-194.

Pampush, G. J., and R. G. Anthony. 1993. Nest success, habitat utilization, and nest-site selection of Long-billed Curlews in the Columbia Basin, Oregon. Condor 95: 957967.

Renaud, W. E. 1980. The Long-billed Curlew in Saskatchewan: status and distribution. Blue Jay 38: 221-237. 
Robbins, M. R. 1998. Display behavior of male Sprague's Pipits. Wilson Bulletin 110: 435-438.

Robbins, M. B., and B. C. Dale. 1999. Sprague's Pipit (Anthus spragueii). In The Birds of North America (439). Edited by A. Poole and F. Gill. The Academy of Natural Sciences, Philadelphia, Pennsylvania; The American Ornithologists' Union, Washington, D.C.

Schmutz, J. K. 1989. Hawk occupancy of disturbed grasslands in relation to models of habitat selection. Condor 91: 362-371.

Shyry, D. T., T. I. Wellicome, J. K. Schmutz, G. L. Erickson, D. L. Scobie, and R. F. Russell. 2001. Burrowing Owl population-trend surveys in southern Alberta: 19912000. Journal of Raptor Research 35: 310-315.

Telfer, E. S., C. Adam, K. De Smet, and R. Wershler. 1989. Status and distribution of the Loggerhead Shrike in western Canada. Canadian Wildlife Services Progress Notes Number 184.4 pages.
Telfer, E. S. 1993. Habitat change as a factor in the decline of the western Canadian Loggerhead Shrike, Lanius ludovicianus, population. Canadian Field-Naturalist 106: 321326.

Todd, L. D., R. G. Poulin, T. I. Wellicome, and R. M. Brigham. 2003. Post-fledging survival of Burrowing Owls in Saskatchewan. Journal of Wildlife Management 67: 512-519.

Wellicome, T. I., and G. L. Holroyd. 2001. The second international Burrowing Owl Symposium: background and context. Journal of Raptor Research 35: 269-273.

Yosef, R. 1996. Loggerhead Shrike (Lanius ludovicianus). In The Birds of North America (231). Edited by A. Poole and F. Gill. The Academy of Natural Sciences, Philadelphia, Pennsylvania; The American Ornithologists Union, Washington, D.C.

Received 2 February 2004

Accepted 27 October 2005 